\title{
Motivation and Vocabulary Breadth in CLIL and EFL Contexts. Different age, Same Time of Exposure
}

\author{
Almudena FERNÁNDEZ FonTECHA \\ Universidad de La Rioja \\ Departamento de Filologías Modernas \\ Almudena.fernandez@unirioja.es
}

\begin{abstract}
Numerous studies have found a positive connection between learners' motivation towards foreign language and foreign language achievement. The present study examines the role of motivation in receptive vocabulary breadth (size) of two groups of Spanish learners of different ages, but all with 734 hours of instruction in English as a Foreign Language (EFL): a CLIL (Content and Language Integrated Learning) group in primary education and a non-CLIL (or EFL) group in secondary education. Most students in both groups were found to be highly motivated. The primary CLIL group slightly overcame the secondary non-CLIL group with respect to the mean general motivation but this is a non-significant difference. The secondary group surpassed significantly the primary group in receptive vocabulary size. No relationship between the receptive vocabulary knowledge and general motivation is found in the primary CLIL group. On the other hand, a positive significant connection, although a very small one, is identified for the secondary non-CLIL group. We will discuss on the type of test, the age of students and the type of instruction as variables that could be influencing the results.
\end{abstract}

Keywords: motivation, EFL receptive vocabulary, Content and Language Integrated Learning (CLIL), time of instruction, age

\section{INTRODUCTION}

Content and Language Integrated Learning (CLIL) is a dual-focused approach that allows students to learn a content subject while being exposed to the foreign language in which this subject is taught (Dalton-Puffer 2008). In the last few decades, the implementation of CLIL is a growing tendency in the European educational setting. In understanding the research findings in studies where the type of instruction is involved, we should single out several possible moderating variables, such as the learners' age, the time of foreign language exposure, and the type of instruction itself, i.e., CLIL vs. EFL (English as a Foreign Language). In EFL the foreign language is not the vehicular language as it is in CLIL. In addition, CLIL requires the implementation of a set of techniques to support both content and foreign language teaching. To know the extent up to which some each of these variables, independent of the others, has some weight on language achievement is an arduous task, since the 
learners' age, which usually goes hand in hand with the educational level, runs parallel to the time of EFL exposure. CLIL entails an increase of exposure independent of the learners' age or educational level. In Spanish education, a typical profile is one in which a learner in a CLIL context receives weekly at least the same hours of exposure to English as a non-CLIL learner plus the hours in English received through the different CLIL subjects. In other cases, the CLIL learner may even receive more hours in English weekly.

This paper attempts to explore the connection between learners' motivation and their EFL receptive vocabulary knowledge. Specifically, it aims to probe into the connection between the size of receptive vocabulary and general, intrinsic and extrinsic motivation of two groups of Spanish learners: a CLIL group in primary education and a non-CLIL group in secondary education. Both groups had received 734 hours of instruction in English, which cancels out the effect of time of exposure.

\subsection{RECEPTIVE VOCABULARY}

Foreign language vocabulary knowledge has become a topic of major importance in the field of Second Language Acquisition (SLA) as a substantial body of research attests in the last decade (e.g. Schmitt 2000, Qian 2002, López Mezquita 2005, Nation 2006, Staehr 2008). Different aspects are of considerable importance within foreign language vocabulary acquisition. A starting point for discussion is the distinction between productive and receptive types of vocabulary knowledge. Nation (2001) explains that whereas receptive knowledge is understood as a passive skill whose performance involves the perception of a word and understanding of its meaning both in listening and reading, productive word knowledge is perceived as an active skill consisting in the production of words to match the speaker's intention in speaking and writing. Nation $(1990,2001)$ and Meara (1996) refer to form, meaning and use as key aspects involved in the learning of a new word both productively and receptively. Research has also examined foreign language learner's types of vocabulary knowledge and concludes that production is a more demanding task than reception (e.g. Laufer and Paribakht 1998, Webb 2008).

Among the tools to measure receptive vocabulary knowledge, the Vocabulary Levels Test (VLT) by Nation $(1983,1990)$ has been widely used and validated in research (Schmitt and Meara 1997; Laufer 1998; Laufer and Paribakht 1998; Cobb and Horst 1999; Schmitt, Schmitt and Clapham 2001; Cameron 2002; Jiménez Catalán and Terrazas 2005-2008; Mokhtar et al. 2010; Agustín Llach and Terrazas Gallego 2012). Traditionally implemented at the university level (Waring 1997, Cobb and Horst 1999, Nurweni and Read 1999, Pérez Basanta 2005, Mokhtar et al. 2010), it has also been used in primary and secondary education (e.g. Laufer 1998, Qian 2002, López-Mezquita 2005, Terrazas and Agustín Llach 2009, Agustín Llach and Terrazas Gallego 2012, Fernández Fontecha and Terrazas Gallego 2012). With the 
purpose of informing vocabulary teaching, the VLT is a word-definition matching test that measures receptive vocabulary breadth (i.e., size or number of words) based on the subjects' recognition of words of graded frequency lists of 2,000, 3,000, 5,000, the Academic Word List (AWL) and the 10,000 most frequent words in English. The test-takers are required to match three definitions to three words out of a list of six target words that belong to a frequency list. The testees must know the six words in order to check them against the given definitions. Knowing words in a frequency band implies knowing words in all lower bands.

Table 1 shows results of different studies conducted in Spain with the 2,000-word frequency-band from the receptive version of the Vocabulary Levels Test (2K VLT), version 2, by Schmitt, Schmitt and Clapham's (2001). These results are arranged according to the number of words known receptively. In general, the results in VLT studies reveal that the number of hours of L2 exposure and the age or educational level has a predominant effect in the receptive vocabulary size.

\begin{tabular}{|c|c|c|l|c|}
\hline Study & $\begin{array}{c}\text { Receptive } \\
\text { Vocabulary } \\
\text { Size (No. of } \\
\text { words) }\end{array}$ & $\begin{array}{c}\text { Hours of } \\
\text { L2 } \\
\text { exposure }\end{array}$ & L1 & Educational level / type of instruction \\
\hline $\begin{array}{c}\text { López- } \\
\text { Mezquita } \\
\text { (2005) }\end{array}$ & 941 & 1049 & Spanish & $\begin{array}{c}\text { Secondary Education (4th secondary/10th } \\
\text { grade) / EFL }\end{array}$ \\
\hline $\begin{array}{c}\text { Canga Alonso } \\
\text { (in press) }\end{array}$ & 935 & 1049 & Spanish & $\begin{array}{c}\text { Secondary Education (4th secondary/10th } \\
\text { grade) / EFL }\end{array}$ \\
\hline $\begin{array}{c}\text { Fernández } \\
\text { Fontecha and } \\
\text { Terrazas } \\
\text { Gallego } \\
\text { (2009) }\end{array}$ & 1215 & 944 & Spanish & $\begin{array}{c}\text { Secondary Education (3rd secondary/9th } \\
\text { grade) / EFL (1st secondary learners of the } \\
\text { present study) }\end{array}$ \\
\hline $\begin{array}{c}\text { Canga Alonso } \\
\text { (2013) }\end{array}$ & 972 & 839 & Spanish & $\begin{array}{c}\text { Secondary Education (2nd secondary/8th } \\
\text { grade) / EFL (subsample of 1st secondary } \\
\text { learners of the present study) }\end{array}$ \\
\hline $\begin{array}{c}\text { Canga Alonso } \\
\text { (2013) }\end{array}$ & 696 & 839 & Spanish & $\begin{array}{c}\text { Primary Education (5th grade) / CLIL } \\
\text { (learners of the present study) }\end{array}$ \\
\hline $\begin{array}{c}\text { Agustín Llach } \\
\text { and Terrazas } \\
\text { Gallego } \\
\text { (2012) }\end{array}$ & 663 & 629 & Spanish & \begin{tabular}{c} 
Primary Education (6th grade) / EFL \\
\hline $\begin{array}{c}\text { Agustín Llach } \\
\text { (2012) }\end{array}$
\end{tabular} \\
\hline $\begin{array}{c}\text { Agustín Llach } \\
\text { (2012) }\end{array}$ & 595 & 419 & Spanish & $\begin{array}{c}\text { Primary education (4th grade) / EFL } \\
\text { (same learners of the present study) }\end{array}$ \\
\hline
\end{tabular}

Table 1. 2 K VLT: average receptive vocabulary size in EFL Spanish learners 


\subsection{MOTIVATION IN FOREIGN LANGUAGE ACQUISITION}

Motivation is not an unknown variable in the field of foreign language acquisition. Its influence in learning in general and in foreign language learning in particular has been traditionally covered in the literature. Different models have attempted to shed some light on this complex relationship of language learning and motivation. To mention some, Gardner and Lambert's (1972) Socio-Psychological Model, SelfDetermination Theory (Deci and Ryan 1985; Noels 2001; Noels, Pelletier, Clément and Vallerand 2000) or Dórnyei's $(2005,2009)$ L2 Motivational Self System. According to Gardner (1985: 11), motivation towards language learning is the desire to achieve that language, the learner's immediate goal, by means of effort, want or desire, and affect or attitude. He points to two types of orientations or learner's ultimate reasons for learning the language: integrative orientation, i.e., learners' willingness to learn the language to become part of the target language community, and instrumental orientation, i.e., learners' desire to command the foreign language for practical reasons. Despite the importance of this attempt in determining the types of motivation, different studies revealed the need for further classifications (Clément and Kruidenier 1983, Crookes and Schmidt 1991). In this line, the Self-Determination Theory classified motivation in terms of (1) extrinsic motivation, based on the external factors that influence foreign language learning, and (2) intrinsic motivation, which refers to the interest generated by the activity itself. Due to the apparent resemblance of these terms and concepts, instant parallelisms could be lightly articulated between instrumental motivation and extrinsic motivation, and between intrinsic motivation and some forms of integrative motivation. However, because of the different conceptualizations of these terms, the utmost caution must be exercised before any association is made.

In the last few decades, a vast amount of studies have examined the connection between learners' motivation towards the foreign language and foreign language achievement. As could be expected, a positive relationship is identified (Schmidt and Watanabe 2001, Masgoret and Gardner 2003, Bernaus and Gardner 2008, Yu and Watkins 2008, Fernández Fontecha 2010). Although the knowledge of words seems to be strongly linked to a necessity or motivation about expressing meanings, the relationship between motivation and foreign vocabulary learning remains almost unexplored (Elley 1989, Gardner and MacIntyre 1991, Laufer and Husltijn 2001, Kim 2008). A recent line of research conducted in the Spanish context focuses on identifying connections between receptive and productive vocabulary knowledge and motivational levels of male and female students in different types of instructional contexts, e.g. CLIL (Content and Language Integrated Learning) (Fernández Fontecha 2010, Fernández Fontecha and Terrazas Gallego 2012, Fernández Fontecha and Canga Alonso in press). 


\subsection{MOTIVATION AND OTHER FACTORS: AGE AND TYPE OF INSTRUCTION}

An issue of major importance is the way motivation towards foreign language interacts with learners' age. Many studies point to a decrease of motivation with age (Chambers 1999; Williams, Burden and Lanvers 2002; Cenoz 2003; Ghenghesh 2010). Tragant (2006) found that secondary education students were more motivated than primary education students, but this tendency stops somewhere in upper secondary education. Motivation becomes stable after secondary education, as Lasagabaster (2003) notes in a research study conducted with university students. Concerning the type of motivation addressed, in a study with CLIL and EFL groups in $7^{\text {th }}$ and $8^{\text {th }}$ grades $\left(1^{\text {st }}\right.$ and $3^{\text {rd }}$ grade of secondary education), Dolz, Lasagabaster and Sierra (2013) find out that the youngest learners show greater intrinsic motivation, but the oldest have more instrumental orientation. In the line of the last study, some studies have focused on examining motivation in Content and Language Integrated Learning (CLIL) and EFL contexts. Most researchers find that motivational levels are higher in CLIL settings (Lasagabaster 2011, Murtagh 2007, Seikkula-Leino 2007). One of the reasons for this result is provided by Dalton-Puffer (2008), who points to the idea that CLIL may make learners lose their inhibitions to use the foreign language in a spontaneous way.

\section{PURPOSE}

Given a group of non-CLIL $1^{\text {st }}$ graders of Spanish secondary education (grade 7) and a group of CLIL $4^{\text {th }}$ graders of primary education who, at the time of data collection, had been exposed to English as a foreign language during 734 hours, this research intends to explore:

1. The levels of general motivation (GMot) together with intrinsic (IMot) and extrinsic (EMot) motivation of the two groups;

2. Their receptive vocabulary knowledge; and

3. Whether there is any connection between the level of motivation towards EFL and the scores obtained by the students in each group in the $2 \mathrm{~K}$ Vocabulary Levels Test.

\section{METHOD}

\subsection{PARTICIPANTS}

Two groups of students took part in this study: a group of $3041^{\text {st }}$ graders of secondary education (grade 7) - aged around 12-13 years old, and a group of 58 CLIL $4^{\text {th }}$ graders of primary education - aged around 9-10 years old. They were 
randomly selected from different mixed-gender school centres with a similar socioeconomic background located in La Rioja (north of Spain). The CLIL students were enrolled in a CLIL regional programme called PILC project (Proyectos de Innovación Lingüística en Centros - School Language Innovative Projects), in which Natural Science was taught through English. At time of testing, both groups had received 734 hours of instruction in English as a Foreign Language (3 hours/week). Thus, whilst each group had been exposed to EFL in the English Language Classroom, the primary group had also received extra hours of EFL through a CLIL subject.

\subsection{INSTRUMENTS, PROCEDURES, AND ANALYSIS}

We use Schmitt, Schmitt and Clapham's (2001) version 2 of the 2,000-word frequency-band from the receptive version of the Vocabulary Levels Test (2K VLT) to measure learners' vocabulary knowledge. The test consists of ten groups of six words and three definitions per group. Testees match each target word to its definition. Correct matching of each target word with its definition is given one point, so that the maximum score of the test is 30 points. In order to calculate students' word estimates, Nation's (1990: 78) formula has been applied: "Vocabulary size $=\mathrm{N}$ correct answers multiplied by total $\mathrm{N}$ words in dictionary (the relevant word list) divided by $\mathrm{N}$ items in test." We gathered data in one regular school time session. Test-takers had 10 minutes to complete the test. Before starting, they were given clear instructions in their mother tongue both orally and in written form.

The assessment of learners' motivation towards EFL is done by means of a semantic differential technique of 7-point bipolar rating scale using the following 7 pairs of bipolar adjectives: 'necessary'/'unnecessary', 'ugly'/"nice', 'attractive'/'unattractive', 'pleasant'/'unpleasant', 'important'/'unimportant', 'useful'/'useless', and 'interesting'/'boring'. These adjectives are introduced with the Spanish phrase "Considero que el inglés es..." ("I consider English to be..."). This scale is part of a questionnaire adapted from Gardner's (1985) Attitude/Motivation Test Battery (A/MTB). Intrinsic motivation is measured through the pairs 'ugly'/'nice', 'attractive'/"unattractive', 'pleasant'/"unpleasant', and 'interesting'/'boring'; the extrinsic motivation is measured through the pairs 'necessary'/'unnecessary', 'important'/'unimportant', and 'useful'/'useless'.

Data from the VLT and the motivation scale were analyzed through SPSS program version 19.0. 


\section{RESULTS}

RQ1. Levels of general motivation (GMot) together with the two types of motivation, intrinsic (IMot) and extrinsic (EMot), of the two groups

In order to answer the first research question of this study, i.e., which are the levels of general motivation (GMot), intrinsic motivation (IMot) and extrinsic motivation (EMot)?, we arranged the scores obtained in the motivation test according to an arbitrary three-level scale ranging from level 1 (marks: 1.0 to 3.0), level 2 (marks: 3.01 to 5.0), and level 3 (marks: 5.01 to 7.0), where 1 is the lowest level of motivation and 7 the highest. The results are almost identical in each group in terms of percentages of number of learners highly, medium and lowly motivated. Most learners in both groups are highly motivated $\left(1^{\text {st }}\right.$ secondary $=62 \%, 4^{\text {th }}$ primary $=$ $62 \%)$, followed by those who are motivated at level $2\left(1^{\text {st }}\right.$ secondary $=33 \%$, $4^{\text {th }}$ primary $=34 \%)$. Very few low-motivated learners are identified $\left(1^{\text {st }}\right.$ secondary $=5 \%$, $4^{\text {th }}$ primary $=4 \%$ ).

Table 2 displays the number of learners per level of general motivation for $1^{\text {st }}$ secondary and $4^{\text {th }}$ primary:

\begin{tabular}{|c|c|c|c|c|}
\hline Motivation levels & $\begin{array}{c}\mathbf{1}^{\text {st }} \text { secondary } \\
(\mathbf{N})\end{array}$ & $\mathbf{\%}$ & $\begin{array}{c}\mathbf{4}^{\text {th }} \text { primary } \\
(\mathbf{N})\end{array}$ & $\mathbf{\%}$ \\
\hline Level 1 & 15 & $5 \%$ & 2 & $4 \%$ \\
\hline Level 2 & 100 & $33 \%$ & 18 & $34 \%$ \\
\hline Level 3 & 188 & $62 \%$ & 33 & $62 \%$ \\
\hline Total & 303 & & 53 & \\
\hline $\begin{array}{c}\text { Missing (students who do not answer } \\
\text { questions) }\end{array}$ & 1 & & 5 & \\
\hline
\end{tabular}

Table 2. Motivation levels: Frequency

Table 3 shows the means of general motivation together with the means of the two types: intrinsic and extrinsic motivation for each group of learners. Standard Deviation as well as minimum and maximum values are added.

\begin{tabular}{|c|c|c|c|c|c|}
\hline Motivation & Grade & Mean & SD & Min. & Max. \\
\hline $\begin{array}{c}\text { General Motivation } \\
\text { (GMot) }\end{array}$ & $1^{\text {st }}$ secondary (non-CLIL) & 5.1855 & 1.1553 & 1.00 & 7.00 \\
\cline { 2 - 6 } & $4^{\text {th }}$ primary (CLIL) & 5.5052 & 1.2278 & 1.00 & 7.00 \\
\hline $\begin{array}{c}\text { Intrinsic Motivation } \\
\text { (IMot) }\end{array}$ & $1^{\text {st }}$ secondary (non-CLIL) & 4.6326 & 1.5233 & 1.00 & 7.00 \\
\cline { 2 - 6 } & $4^{\text {th }}$ primary (CLIL) & 5.3396 & 1.4944 & 1.00 & 7.00 \\
\hline $\begin{array}{c}\text { Extrinsic Motivation } \\
\text { (EMot) }\end{array}$ & $1^{\text {st }}$ secondary (non-CLIL) & 6.2504 & 1.1930 & 1.00 & 7.00 \\
\cline { 2 - 6 } & $4^{\text {th }}$ primary (CLIL) & 6.0754 & 1.3181 & 1.00 & 7.00 \\
\hline
\end{tabular}

Table 3. Means of general, intrinsic and extrinsic motivation 
A Wilcoxon rank sum test is performed to detect no significant differences between the two groups in GMot ( $\mathrm{p}$-value $=0.057)$, IMot $(\mathrm{p}$-value $=0.001)$, nor in EMot (0.612).

\section{RQ2. Receptive vocabulary knowledge}

The second research question attempts to examine the size of receptive vocabulary knowledge. Table 4 presents the descriptive statistics for results on the $2 \mathrm{~K}$ VLT for the two groups, in which the different word estimates obtained by them are included. These results mean that the average receptive vocabulary size of both groups is within the 1,000 frequency level. However, the difference is big: while the group of $1^{\text {st }}$ secondary learners recognizes 779 words from the band of the first 1,000 most frequent words in English, the $4^{\text {th }}$ primary CLIL group recognizes 471.26. Being the time of instruction the same in both cases and independently of the type of instruction, i.e., CLIL vs. non-CLIL, the $1^{\text {st }}$ secondary group overcomes the $4^{\text {th }}$ primary group in receptive vocabulary size.

A Wilcoxon rank sum test identifies that these differences in receptive vocabulary size are significant $(\mathrm{p}$-value $=5.186 \mathrm{e}-12)$.

\begin{tabular}{|c|c|c|c|c|c|}
\hline Groups & Min. & Max. & Mean & SD & $\begin{array}{c}\text { Word } \\
\text { estimates }\end{array}$ \\
\hline $1^{\text {st }}$ secondary (non-CLIL) & 1 & 24 & 11.69 & 4.57 & 779.54 \\
\hline $4^{\text {th }}$ primary (CLIL) & 1 & 17 & 7.07 & 3.67 & 471.26 \\
\hline
\end{tabular}

Table 4. Descriptive statistics: 2 K VLT

RQ3. Connection between the level of motivation towards EFL and the scores obtained by the students in each group in the $2 K$ Vocabulary Levels Test

Following, we explain the results obtained by each of the groups with regard to the possible relationship between level of general motivation, intrinsic and extrinsic types and the results of the $2 \mathrm{~K}$ Vocabulary Levels Test.

A Lilliefors (Kolmogorov-Smirnov) normality test was performed with the $1^{\text {st }}$ secondary data. Normal distribution cannot be accepted concerning any result (VLT: p-value $=0.0025 ;$ GMot: -value $=5.989 \mathrm{e}-08 ; \mathrm{p}$-value $=2.37 \mathrm{e}-08 ;$ EMot: $\mathrm{p}$-value $<$ 2.2e-16). Spearman correlation test is used. The correlation between the $2 \mathrm{~K}$ VLT and the different types of motivation is significant in each case (GMot: $\mathrm{p}$-value $=2.816 \mathrm{e}-$ 09; IMot: $p$-value $=1.275 \mathrm{e}-05$; EMot: $\mathrm{p}$-value $=2.397 \mathrm{e}-06$ ). In the three cases the relationship is positive. Figure 1 shows the positive correlation between general motivation and receptive vocabulary.

In the analysis of the VLT results by the $4^{\text {th }}$ primary (CLIL) group, a Shapiro-Wilk normality test is performed. The normality can be accepted ( $p$-value $=0.06$ ). Yet, no normal distribution is identified in the motivation results. By means of a Spearman 
correlation test, we identify no significant relationship between the $2 \mathrm{~K}$ VLT and the GMot, IMot, and EMot. In all cases the p-values are higher than 0.05: GMot (p-value $=0.16)($ Figure 2$)$, IMot $(\mathrm{p}$-value $=0.23)$, and EMot $(\mathrm{p}$-value $=0.13)$. Table 5 displays the results for both groups:

\begin{tabular}{|c|c|c|c|c|c|c|}
\hline Groups & GMot & $\begin{array}{c}\text { IMot and } \\
\text { 2K VLT }\end{array}$ & $\begin{array}{c}\text { EMot } \\
\text { and 2K } \\
\text { VLT }\end{array}$ & \\
\hline & rho & p-value & rho & p-value & rho & p-value \\
\hline $\begin{array}{c}1^{\text {st }} \text { secondary } \\
(\mathrm{n}=304)\end{array}$ & 0.33 & $\begin{array}{c}2.816 \mathrm{e}- \\
09\end{array}$ & 0.24 & $\begin{array}{c}1.275 \mathrm{e}- \\
05\end{array}$ & 0.26 & $\begin{array}{c}2.397 \mathrm{e}- \\
06\end{array}$ \\
\hline $\begin{array}{c}4^{\text {th }} \text { primary CLIL } \\
(\mathrm{n}=58)\end{array}$ & 0.19 & 0.16 & 0.16 & 0.23 & 0.20 & 0.13 \\
\hline
\end{tabular}

Table 5. Correlation GMot, IMot, EMot and $2 \mathrm{~K}$ VLT

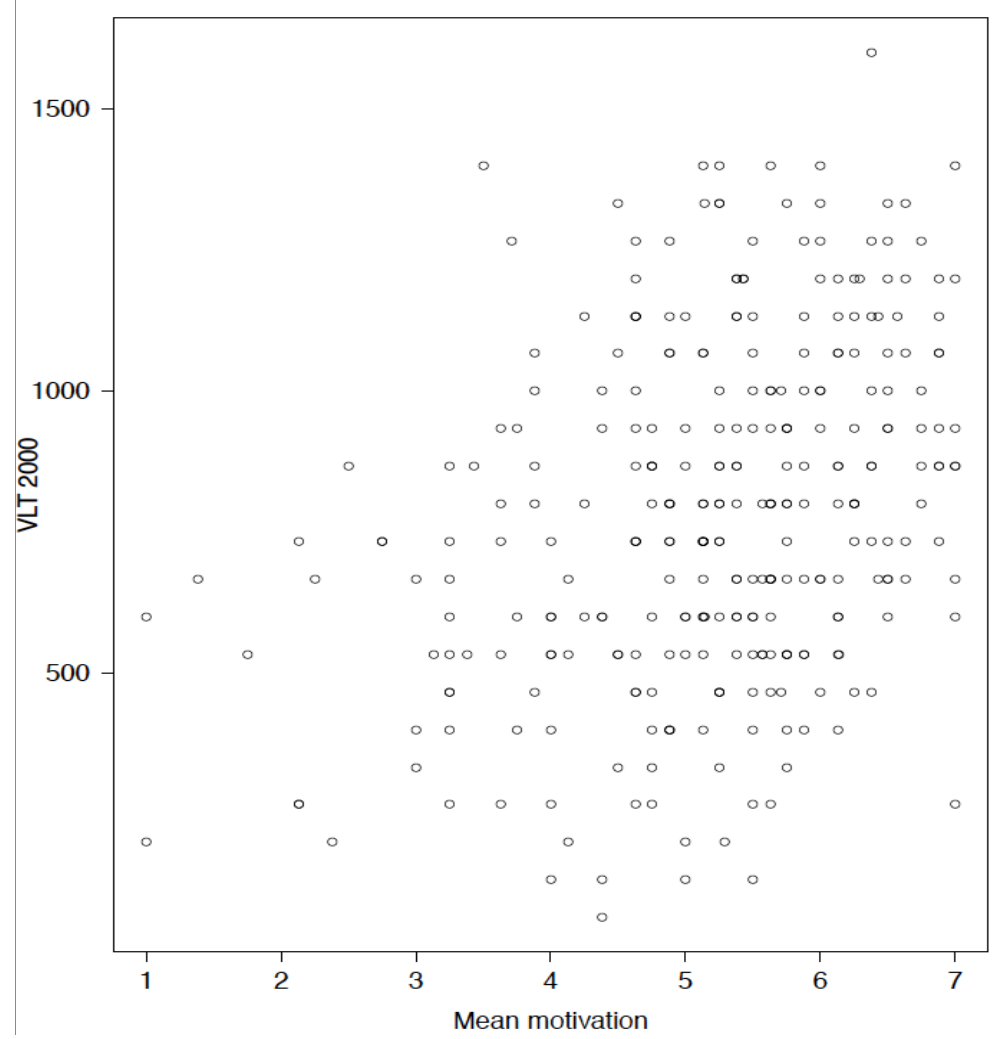

Figure 1. $1^{\text {st }}$ secondary: positive correlation $2 \mathrm{~K}$ VLT - GMot $(p$-value $<0.05$, cor $=0.33$ ) 


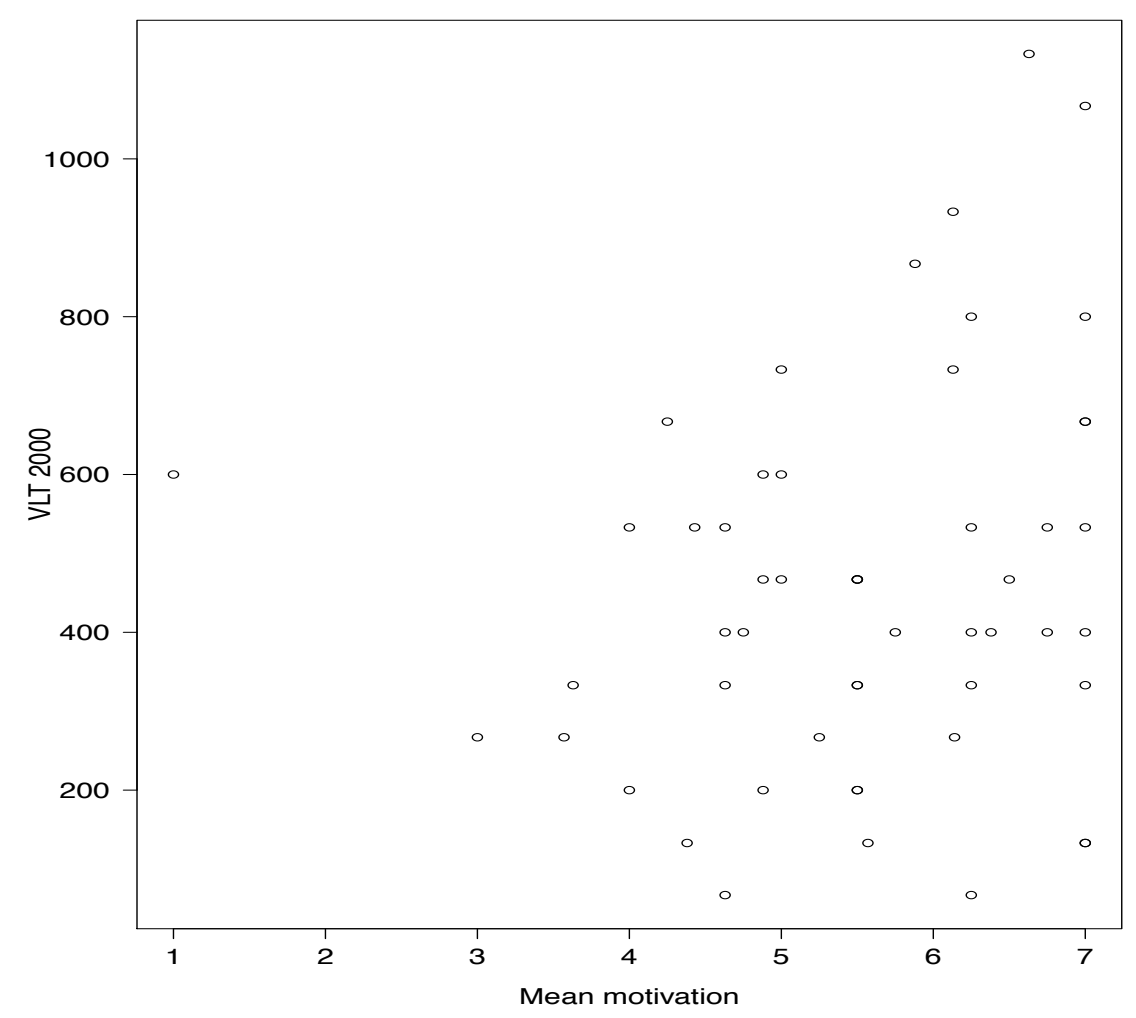

Figure 2. $4^{\text {th }}$ primary: no correlation $2 K$ VLT - GMot $(p$-value $>0.05$, cor $=0.19)$

\section{DISCUSSION}

According to our first research question on what levels of GMot, IMot and EMot are identified in the two groups of learners, a high coincidence in the percentage of the number of participants at each of the three levels of GMot is found. In both cases, more than half of the students were highly motivated, followed by around $35 \%$ of students motivated at level 2 . Only around $5 \%$ of the students were motivated at level 1 .

To give a wider understanding of the results on motivation, the results obtained with the same students in two further unpublished studies should be mentioned: Fernández Fontecha under review a; and Fernández Fontecha under review b. In general, the distribution of $1^{\text {st }}$ secondary non-CLIL students per levels of motivation improves in the next two years, when the motivation of a sub-sample of 186 students is explored at $2^{\text {nd }}$ secondary education (level $3=65 \%$, level $2=32 \%$, level $1=2 \%$ ) 
(Fernández Fontecha under review a), and at $3^{\text {rd }}$ secondary (level $3=71 \%$, level $2=$ $25 \%$, level $1=3 \%$ ) (Fernández Fontecha under review b). Yet, one should be cautious in interpreting these results since the $1^{\text {st }}$ secondary education sample $(\mathrm{N}=304)$ doubles the number of participants of the $2^{\text {nd }}$ and $3^{\text {rd }}$ secondary education samples. We also observe an improvement in the distribution of the $4^{\text {th }}$ primary CLIL students when they move up a grade $\left(5^{\text {th }}\right.$ primary CLIL, $\left.\mathrm{N}=55\right)$ : level $3: 76 \%$, level $2: 13 \%$. No students reported low motivation (Fernández Fontecha under review a).

With respect to the means of the different types of motivation, there are no significant differences between the groups. However, certain trends can be identified. In both groups the EMot is higher than the IMot. If we consider the differences between groups, the $4^{\text {th }}$ primary CLIL group surpasses the $1^{\text {st }}$ secondary non-CLIL group in GMot (5.50 vs. 5.18) and IMot (5.33 vs. 4.63) but not in EMot (6.07 vs. 6.25). In general, these results coincide with results of research on types of motivation and age (Doiz, Lasagabaster and Sierra 2013), according to which younger learners are more intrinsically motivated than older learners, who are more instrumentally motivated.

The second research question addresses the learners' size of receptive vocabulary knowledge, i.e. number of words learners know receptively. This size is bigger in the $1^{\text {st }}$ secondary non-CLIL group.

Being the time of exposure to EFL the same in our two samples, the superiority of the $1^{\text {st }}$ secondary non-CLIL group may imply that the educational level or the age (cognitive level) is determining learners' receptive vocabulary knowledge. Our evidence is in line with Canga Alonso (2013), who explores the receptive vocabulary knowledge of some sub-groups of the participants of our study in the following year, i.e., in $5^{\text {th }}$ primary CLIL and $2^{\text {nd }}$ secondary education. He identifies that with the same time of L2 exposure, the $2^{\text {nd }}$ secondary group surpasses the $5^{\text {th }}$ primary CLIL group in receptive vocabulary size. This is a statistically significant difference.

These results contradict those obtained in other $2 \mathrm{~K}$ VLT studies where the type of instruction - or the time of L2 exposure - is also having some role in receptive vocabulary knowledge (Table 1). Thus, the $5^{\text {th }}$ primary CLIL group in Canga Alonso's (2013) research slightly surpasses a $6^{\text {th }}$ primary non-CLIL group in a study by Agustín Llach and Terrazas Gallego (2012). Yet, Agustín Llach observes that a group of $4^{\text {th }}$ primary non-CLIL graders outstrips a sub-sample of the same $4^{\text {th }}$ primary CLIL graders of our study, although the difference is not significant. Further studies replicating these results are needed.

As for the connection between level of motivation towards EFL and the learners' scores in the $2 \mathrm{~K}$ Vocabulary Levels Test, our third research question, there exists a significant positive correlation between both for the $1^{\text {st }}$ secondary group, which indicates that the higher the learner's GMot, IMot or EMot, the higher his/her receptive vocabulary size is, or vice versa. However, although positive, the correlation is not big, which implies that other variables could be affecting this result. It is interesting to mention here that, while no link was identified between the 
receptive vocabulary size and motivation of $1862^{\text {nd }}$ secondary graders - a sub-sample of our $1^{\text {st }}$ secondary group - a significant correlation was found between both variables in the same 186 students in $3^{\text {rd }}$ secondary grade (Fernández Fontecha and Terrazas Gallego 2012).

As regards the $4^{\text {th }}$ primary CLIL learners, we found no significant relationship between their $2 \mathrm{~K}$ VLT outcomes and their GMot, IMot, and EMot. Yet, in the study conducted by Fernández Fontecha (under review a), a significant correlation was identified between both GMot and the results of the $2 \mathrm{~K}$ VLT, although no relationship was perceived between the $2 \mathrm{~K}$ VLT and the two types of motivation in a group of 55 students out of the 58 primary CLIL students of the present sample in $5^{\text {th }}$ primary grade.

Hence, no conclusive evidence can be adduced of the connection between receptive vocabulary knowledge and motivation. Following Tseng and Schmitt (2008), one of the reasons behind these findings may be the fluctuating nature of vocabulary and motivation.

\section{CONCLUSION}

This study has contributed to furthering the understanding of L2 achievement in CLIL and non-CLIL instruction. For that purpose, we have explored the relationship between motivation and receptive vocabulary knowledge of two groups of students of different grades $\left(4^{\text {th }}\right.$ primary CLIL and $1^{\text {st }}$ secondary non-CLIL education). The number of hours of EFL instruction is the same in both groups of learners, although not their age. While the primary group is aged around 9-10 years old, the secondary education group is aged around 12-13 years old.

As regards motivation towards EFL, high motivation levels and quite similar distribution patterns across levels are identified in both groups. Complementary research reports that the general motivation of each group increases in the following years. A follow-up study is needed to explore the moment at which this increasing tendency changes: whether, as Lasagabaster (2003) notes, after secondary education, or at any other point of language learning.

On the other hand, with respect to the results in receptive vocabulary acquisition, the secondary non-CLIL group obtains better results in the $2 \mathrm{~K}$ VLT. This result may lead to several conclusions. On the one hand, given the same hours of exposure to English as a foreign language, this finding suggests that the learners' age or their cognitive level may affect the result. On the other hand, in order to adduce some kind of conclusive evidence of which effect the type of instruction is having on the findings, further studies are needed that cancel out the effect of learners' age. To cope with this difficulty, different data gathering times could be planned in CLIL and nonCLIL groups of learners of the same age to even out instruction times. 
As for the link between motivation and receptive vocabulary size, a significant connection is found between both in the secondary group, although it is small and therefore other variables can be influencing this result. In the primary group, no connection is identified. These results do not serve to establish a trend in studies that combine these two variables. A variety of results are obtained in this regard. No link is identified in a sub-sample of the $1^{\text {st }}$ secondary group, but it is observed in the same group in $3^{\text {rd }}$ secondary grade (Fernández Fontecha and Terrazas Gallego 2012). The same lack of a clear tendency is noted in the $4^{\text {th }}$ primary CLIL group, which in $5^{\text {th }}$ grade shows a connection between general motivation and 2K VLT (Fernández Fontecha under review a).

Longitudinal studies are needed to identify evolution of relationship of motivation and vocabulary as two dynamic and fluctuating processes (Tseng and Schmitt 2008), which involve a myriad of aspects to look upon. Derived from this investigation, it would be interesting to explore the behaviour and evolution of the relationship between motivation and the different types of vocabulary, since existing research conducted with students in the same year points to differences in motivation and receptive vocabulary (Fernández Fontecha and Terrazas Gallego 2012) and productive vocabulary (Fernández Fontecha 2010). Further research in this line should also incorporate other instruments to measure motivation and related aspects, such as Dórnyei's $(2005,2009)$ L2 Motivational Self System or the Willingness To Communicate test by MacIntyre et al. (2002).

\section{ACKNOWLEDGEMENTS}

This study is part of the research project "Factores individuales y contextuales en la adquisición y desarrollo de la competencia léxica en inglés como lengua extranjera" funded by the Spanish Ministerio de Ciencia e Innovación (Grant Ref. No.: FFI201019334/FILO). We are also very thankful to our statistician Montserrat San Martin for providing us with very valuable statistical assistance and helpful insights into data interpretation. Any remaining errors are our own.

\section{REFERENCES}

Agustín Llach, M. ${ }^{a}$ Pilar (2012). Exploring the receptive vocabulary of young CLIL and non-CLIL learners. Paper presented at Eurosla22, Poznan, Poland, September 2012.

Agustín Llach, M. ${ }^{a}$ Pilar and Melania Terrazas Gallego (2012). Vocabulary Knowledge Development and Gender Differences in a Second Language. ELIA 12: 45-75. <http://institucional.us.es/revistas/elia/12/art_3.pdf $>$ (Accessed November 6 2015). 
Bernaus, Mercedes and Robert C. Gardner (2008). Teacher Motivation Strategies, Student Perceptions, Student Motivation, and English Achievement. The Modern Language Journal 92.3: 387-401.

Cameron, Lynne (2002). Measuring vocabulary size in English as an additional language. Language Teaching Research 6.2: 145-73.

Canga Alonso, Andrés (2013). The receptive vocabulary of Spanish students in CLIL and Non-CLIL instruction. A Journal of Anglo-American Studies 2, Second Series.

Canga Alonso, Andrés (in press). Receptive vocabulary size of Spanish EFL learners at secondary school. Revista de Lingüistica y Lenguas Aplicadas 8.

Canga Alonso, Andrés and Almudena Fernández Fontecha (under review). Motivation and L2 receptive vocabulary knowledge of Spanish EFL students at the Official School of Languages.

Cenoz, Jasone (2003). El aprendizaje del inglés desde educación infantil: efectos cognitivos, lingüísticos y afectivos. Eduling 1.

Chambers, Gary N. (1999). Motivating language learners. Clevedon: Multilingual Matters.

Clément, Richard and Bastian G. Kruidenier (1983). Orientations in Second Language Acquisition: I. The Effects of Ethnicity, Milieu, and Target Language on their Emergence. Language Learning 33: 273-291.

Cobb, Tom and Marlise E. Horst (1999). Vocabulary sizes of some city University students. Journal of the Division of Language Studies of City University of Hong Kong 1.1. <http://www.er.uqam.ca/nobel/r21270/cv/CitySize.html> (Accessed November 6 2015).

Crookes, Graham and Richard W. Schmidt (1991). Motivation Reopening the Research Agenda. Language Learning 41.4: 469-512.

Dalton-Puffer, Christiane (2008). Outcomes and processes in Content and Language Integrated Learning (CLIL): Current research from Europe. In Werner Delanoy and Laurenz Volkmann, eds., 139-157.

Deci, Edward L. and Richard M. Ryan (1985). Intrinsic Motivation and SelfDetermination in Human Behavior. New York: Plenum Publishing Co.

Doiz, Aintzane; David Lasagabaster and Juan Manuel Sierra (2013) The impact of individual and contextual variables on motivation. Paper presented at the Applied Linguistics Perspectives on Content and Language Integrated Learning (ALPCLIL), Miraflores de la Sierra, Madrid, June 2013.

Dörnyei, Zoltán (2003). Attitudes, Orientations and Motivations in Language Learning. Oxford: Blackwell.

Dörnyei, Zoltán (2005). The Psychology of the Language Learner: Individual Differences in Second Language Acquisition. Mahwah, NJ: Lawrence Erlbaum.

Dörnyei, Zoltán. (2009). The L2 motivational self system. In Zoltán Dörnyei and Ema Ushioda, eds., 92-142.

Dörnyei, Zoltán and Ema Ushioda (2009). Motivation, Language Identity and the L2 Self. Bristol: Multilingual Matters. 
Dörnyei, Zoltán and Richard Schmidt (2001). Motivation and Second Language Acquisition (Technical Report \#23). Honolulu: University of Hawaii, Second Language Teaching and Curriculum Center.

Elley, Warwick B. (1989). Vocabulary Acquisition from Listening to Stories. Reading Research Quarterly 24: 174-187.

Fernández Fontecha, Almudena (2010). Gender and motivation in EFL vocabulary production. In Rosa M. Jiménez Catalán, ed., 93-116.

Fernández Fontecha, Almudena (under review a). Receptive vocabulary knowledge and motivation in CLIL and EFL.

Fernández Fontecha, Almudena (under review b). EFL vocabulary size and motivation in CLIL primary and non-CLIL secondary education.

Fernández Fontecha, Almudena and Andrés Canga Alonso (in press). A preliminary study on motivation and gender in CLIL and non-CLIL types of instruction. International Journal of English Studies (IJES) 14.1.

Fernández Fontecha, Almudena and Melania Terrazas Gallego (2012). The role of motivation and age in vocabulary knowledge. VIAL 9: 39-62.

Gardner, Robert C. (1985). Social Psychology and Second Language Learning. London: Edward Arnold.

Gardner, Robert C. and Peter. D. MacIntyre (1991). An instrumental motivation in language study: who says it isn't effective? Studies in Second Language Acquisition 13.1: 57-72.

Gardner, Robert C. and Wallace E. Lambert (1972). Attitudes and Motivation in Second Language Learning. Rowley, MA: Newbury.

Ghenghesh, Pauline (2010). The motivation of L2 learners: does it decrease with age? English Language Teaching 3.1: 128-141.

Jiménez Catalán, Rosa M. ${ }^{a}$ (2010). Gender Perspectives on Vocabulary in Foreign and Second Languages. London: Palgrave Macmillan.

Jiménez Catalán, Rosa M. ${ }^{\mathrm{a}}$ and Melania Terrazas (2005-2008). The receptive vocabulary of English foreign language young learners. Journal of English Studies 5-6: 173-191.

Kim, YouJin (2008). The role of task-induced involvement and learner proficiency in L2 vocabulary acquisition. Language Learning 58.2: 285-325.

Lasagabaster, David (2003). Trilinguismo en la enseñanza: Actitudes hacia la lengua minoritaria, la mayoritaria y la extranjera. Lleida: Milenio.

Lasagabaster, David (2011). English achievement and student motivation in CLIL and EFL settings. Innovation in Language Learning and Teaching 5: 3-18.

Laufer, Bhatia (1998). The development of passive and active vocabulary in a second language: same or different? Applied Linguistics 19.2: 255-271.

Laufer, Bhatia and Tahereh Sima Paribakht (1998). The relationship between passive and active vocabularies: Effects of language learning context. Language Learning 48: 365-391. 
Laufer, Bhatia. and Jan Hulstijn (2001). Incidental vocabulary acquisition in a second language: the construct of task-induced involvement. Applied Linguistics 22: 1-26. López-Mezquita Molina, M. ${ }^{\mathrm{a}}$. Teresa (2005). La Evaluación de la Competencia Léxica: Tests de Vocabulario. Su Fiabilidad y Validez. Ph.D. diss., Universidad de Granada.

MacIntyre, Peter D.; Susan C. Baker, Richard Clément and Leslie A. Donovan (2002). Sex and age effects on willingness to communicate, anxiety, perceived competence, and motivation among junior high school French immersion students. Language Learning 52: 537-564.

Martínez-Dueñas, José Luis; Neil Mclaren, Carmen Pérez Basanta and Luis Quereda Rodríguez-Navarro (2005). Towards an understanding of the English language: past, present and future. Studies in honour of Fernando Serrano. Granada: Universidad de Granada.

Masgoret, Anne-Marie and Robert C. Gardner (2003). Attitudes, motivation, and second language learning: meta-analyses of studies by Gardner and associates. In Zoltán Dörnyei, ed., 167-210.

Meara, Paul (1996). The dimensions of lexical competence. In G. Brown, K. Malmkjaer and J. Williams, eds., Performance and Competence in Second Language Acquisition (pp. 35-53). Cambridge: Cambridge University Press.

Mokhtar, Ahmad Azman; Rafizah Mohd Rawian, Mohamad Fadhili Yahaya, Azaharee Abdullah, Mahani Mansor, Mohd Izwan Osman, Zahrullaili Ahmad Zakaria, Aminarashid Murat, Surina Nayan and Abdul Rashid Mohamed (2010). Vocabulary knowledge of adult ESL learners. English Language Teaching 3.1: 71-80.

Murtagh, Lelia (2007). Out-of-school use of Irish, motivation to learn the language and proficiency in immersion and subject-only post-primary programmes. International Journal of Bilingualism and Bilingual Education 10.4: 428-453.

Nation, Paul (1983). Teaching and testing vocabulary. Guidelines 5: 12-25.

Nation, Paul (1990). Teaching and learning vocabulary. New York: Newbury.

Nation, Paul (2001). Learning Vocabulary in Another Language. Cambridge: Cambridge University Press.

Nation, Paul (2006). How large a vocabulary is needed for reading and listening? The Canadian Modern Language Review/La revue canadienne des langues vivantes 63.1: 59-81.

Noels, Kimberly A. (2001). Learning Spanish as a Second Language: Learners' orientations and perceptions of their teachers' communication style. Language Learning 51: 107-144.

Noels, Kimberly A.; L. G. Pelletier, R. Clément, and R. J. Vallerand (2000). Why are you learning a second language? Motivational orientations and Self-Determination Theory, Language Learning 50: 57-85.

Nurweni, Ari and John Read (1999). The English vocabulary knowledge of Indonesian University Students. English for Specific Purposes 18: 161-75. 
Pérez Basanta, Carmen (2005). Assessing the receptive vocabulary of Spanish students of English Philology: An empirical investigation. In José Luis MartínezDueñas, Neil Mclaren, Carmen Pérez Basanta and Luis Quereda RodríguezNavarro, eds., 1-21.

Qian, David D. (2002). Investigating the relationship between vocabulary knowledge and academic reading performance: An assessment perspective. Language Learning, 52.3: 513-36.

Schmidt, Richard and Yuichi Watanabe (2001). Motivation, strategy use, and pedagogical preferences in foreign language learning. In Zoltán Dörnyei and Richard Schmidt, eds., 313-359.

Schmitt, Norbert (2000). Vocabulary acquisition. In Norbert Schmitt, ed., Vocabulary in Language Teaching (pp. 116-141). Cambridge: Cambridge Language Education.

Schmitt, Norbert and Paul Meara (1997). Researching vocabulary through a word knowledge framework: word associations and verbal suffixes. Studies in Second Language Acquisition 19: 17-35.

Schmitt, Norbert, Dianne Schmitt and Caroline Clapham (2001). Developing and exploring the behaviour of two new versions of the Vocabulary Levels Test. Language Testing 18: 55-88.

Seikkula-Leino, Jaana (2007). CLIL Learning: Achievement Levels and Affective Factors, Language and Education 21.4: 328-341.

Staehr, Lars Stenius (2008). Vocabulary size and the skills of listening, reading and writing. Language Learning Journal 36: 139-152.

Terrazas Gallego, Melania and M. ${ }^{a}$ Pilar Agustín Llach (2009). Exploring the increase of receptive vocabulary knowledge in the foreign language: A longitudinal study. IJES: International Journal of English Studies 9.1: 113-133.

Tragant, Elsa (2006). Language learning motivation and age. In Carmen Muñoz, ed., Age and the Rate of Foreign Language Learning (pp. 237-268). Clevedon: Multilingual Matters.

Tseng, Wen-Ta and N. Schmitt (2008). Toward a Model of Motivated Vocabulary Learning: A Structural Equation Modelling Approach. Language Learning 58.2: 357-400.

Waring, Robert (1997). A comparison of the receptive and productive vocabulary sizes of some second language learners. Immaculata occasional papers of Notre Dame Seishin University 1: 53-68.

Webb, Stuart (2008). Receptive and productive vocabulary sizes of L2 learners. Studies in Second Language Acquisition 30.1: 79-95.

Werner, Delanoy and Laurenz Volkmann (2008). Future Perspectives for English Language Teaching. Heidelberg: Carl Winteer.

Williams, Marion, Robert L. Burden and Ursula Lanvers (2002). French is the language of love and stuff. British Educational Research Journal 28.4: 503-528. 
Yu, Baohua and David A. Watkins (2008). Motivational and cultural correlates of second language acquisition: an investigation of international students in the universities of the People's Republic of China. Australian Review of Applied Linguistics 31.2: 17.1-17.22. 